\title{
Application of endomycorrhizae to commercial production of Rhododendron microplants
}

\author{
MC Lemoine, S Gianinazzi, V Gianinazzi-Pearson * \\ INRA-CNRS, laboratoire de Phytoparasitologie, Station de génétique et d'amélioration des plantes, \\ INRA, BV 1540, 21034 Dijon Cedex, France \\ (COST Meeting, 21-23 May 1992, Dijon, France)
}

\begin{abstract}
Summary - Rhododendron plants produced in vitro are weaned under greenhouse conditions but $\approx 10 \%$ of the microplants either die or do not grow during this stage. A series of experiments was carried out to determine whether production could be increased through controlled mycorrhization. Of 7 fungi isolated from roots of plants sampled in a commercial nursery (Derly France, SA), 1 was mycorrhizal and 6 caused significant damage, showing the need to disinfect substrata before outplanting. Of 5 combinations of $\mathrm{pH}$ and substrata tested, only 1 was suitable for both plant growth and mycorrhization. Screening of different strains of ericoid mycorrhizal fungi from our laboratory against microplants of 9 cultivars of $R$ hybrida indicated a physiological specificity between fungi and plants. These results show that the use of defined disinfected substrata, combined with specific mycorrhizal fungal strains, is essential for guaranteeing an optimal production of outplanted Rhododendron microplants at the nursery level.
\end{abstract}

endomycorrhiza / Rhododendron / microplants / nursery substratum

Résumé - Application de l'endomycorhization à la production commerciale de plants de Rhododendron micropropagés. Les plants de Rhododendron issus de culture in vitro subissent environ $10 \%$ de pertes lors de leur acclimatation en serre. Des essais de mycorhization contrôlée ont été effectués pour tenter d'améliorer le système de production. L'examen de racines de plantes prélevées en pépinières a révélé la présence de 7 champignons différents parmi lesquels 1 est endomycorhizogène et 6 sont défavorables à la culture, d'où la nécessité de désinfecter le substrat avant le repiquage des jeunes vitroplants. L'utilisation de 5 combinaisons différentes de substrats et de pH a permis de déterminer des conditions de cultures optimales. Un criblage entre plusieurs isolats de champignons endomycorhiziens et différents cultivars de Rhododendron a indiqué l'existence d'une spécificité physiologique entre les 2 partenaires. Ces résultats montrent que l'utilisation d'un substrat sélectionné et désinfecté associée à une endomycorhization controlée serait essentielle à l'optimisation de la production en pépinière de Rhododendron issus de vitroplants.

endomycorhizes / Rhododendron / micropropagation / pépinière

\section{INTRODUCTION}

Ericaceous plants constitute an important part of the ornamental horticulture business. About $50 \%$ of the production is based on micropropagated plants, but at weaning $\approx 10 \%$ of plants either die or do not attain market standards, causing significant losses at the commercial level. Mycorrhizal infection of $R$ hododendron has been studied (Peterson et al, 1980; Duddridge, Read, 1982; Moore-Parkhurst, Englander, 1981, 1982; Doug- las et al, 1989) and has frequently been shown to enhance mineral nutrition and growth of ericaceous plants such as Calluna vulgaris L, Vaccinium or Rhododendron species (GianinazziPearson, Gianinazzi, 1981; Beaujard, 1982; Read, Bajwa, 1985; Straub, 1988). A series of experiments was therefore carried out to test the efficiency of controlled mycorrhization for survival of Rhododendron clones and therefore for improvement of the production system of this ornamental plant.

\footnotetext{
* Correspondence and reprints
} 


\section{MATERIALS AND METHODS}

Rhododendron hybrida microplants, provided by "Pépinières Derly France", were outplanted and weaned under growth chamber conditions $\left(23^{\circ} \mathrm{C}, 16-\mathrm{h}\right.$ day, $90 \%$ relative humidity) for 3 months. The different nursery substrata used for experimentation were sterilized by $\gamma$-irradiation (10 KGy). Nutrient solution (Liquo Plant FD2, Plantin) was applied twice a week and plant fresh mass was measured after 8 wk growth. Endomycorrhizal infection was estimated as percent root colonization. Ten replicate plants were used per treatment and data were analysed by ANOVA and Newman-Keuls test.

\section{Fungal isolates}

Indigenous fungi were isolated from 4-3-month-old nursery Rhododendron plants growing in bf 3 substratum (Hydroazote, Lyon). Roots were washed in sterile water and disinfected with antibiotics according to Pearson and Read (1973). Small root pieces were incubated in water agar and the fungi growing out were isolated. Seven isolates were obtained. These and 5 isolates of known ericoid endomycorrhizal fungi from our laboratory (Ipae 9, 13, 15, 25, 42) were grown for $14 \mathrm{~d}$ in Norkrans liquid medium with 20 ppm phosphorus, mycelium was filtered, washed, macerated and suspended in water; each plant received $1 \mathrm{ml}$ of this inoculum suspension. Isolates Ipae 25 and 42 were identified as Hymenocyphus ericae Korf and Kernan, whilst the others were unidentified ascomycetes.

\section{Substrata tested}

Five nursery substrata were tested for growth and mycorrhization (Ipae 25) of 4 clones $(124,206,209,282)$ of Rhododendron microplants: bf 3 at $\mathrm{pH} 4.5$, bf 3 at $\mathrm{pH}$ 6.0 , Stekmedium (Klassman), Hortipro (Wogesal) and Floratorf (Floragard).

\section{Screening of fungal isolates}

Nine clones of Rhododendron (110, 117, 119, 136, $200,201,209,212,232$ ) were outplanted into substratum bf 3 and inoculated either with 1 of the 5 different isolates of ericoid endomycorrhizal fungi or with a mixture of the 5 isolates. The 7 fungi isolated from nursery plants were tested individually by inoculating one
Rhododendron clone (126). Controls were uninoculated plants.

\section{RESULTS AND DISCUSSION}

\section{Indigenous fungi}

In spite of intensive fungicide treatments (2 or 3 fungicides $^{\star}$ and insecticides ${ }^{\star *}$ were applied twice weekly at the nursery stage) seven fungi were isolated $(A-G)$ from Rhododendron roots (table I). Among these 7 isolates, only one (A) was mycorrhizal and presented a typical infection pattern (intracellular hyphal coils in $90 \%$ of the roots). Plants inoculated with this isolate showed good growth, similar to that obtained with isolate lpae 25 , both isolates giving more homogenous populations. The other 6 isolates $(B-G)$ caused significant damage to the microplants, which in some cases died, and only a few plants showed normal growth. These results indicate that fungicide treatments were not sufficient to eliminate all the fungi from the substrata and that it is advisable to disinfect the substrata before outplanting Rhododendron microplants.

Table I. Effects of fungi isolated from roots of Rhododendron microplants on growth of clone 126.

$\begin{array}{ccc}\begin{array}{l}\text { Fungal } \\ \text { strains }\end{array} & \begin{array}{c}\text { Fresh mass } \\ (\mathrm{mg})\end{array} & \begin{array}{c}\% \text { coefficient } \\ \text { of variation }\end{array}\end{array}$

$\begin{array}{lrr}\text { A } & 2161^{a^{\star}} & 11.38 \\ B & 507^{\mathrm{b}} & 37.31 \\ \mathrm{C} & 377^{\mathrm{b}} & 57.55 \\ \mathrm{D} & 14^{\mathrm{c}} & 16.76 \\ \mathrm{E} & 625^{\mathrm{b}} & 15.49 \\ \mathrm{~F} & 94^{\mathrm{b}} & 36.36 \\ \text { G } & 539^{\mathrm{b}} & 37.00 \\ \text { lpae 25 } & 1817^{\mathrm{a}} & 8.53\end{array}$

\footnotetext{
Values for each clone followed by different letters are significantly different at $95 \%$ confidence levels.
}

\footnotetext{
* Procymidone: Sumisclex; vinchlozoline: Ronilan; zirame: Pomarsol; iprodione: Rovral; prothiocarb: Previcur; benomyl: Benlate.

** Deltamethrine: Decis; dichlorvos: Dedevap; methomyl: Lannate.
} 


\section{Nursery substrata}

There was a significant effect of the different substrata on growth of the 4 tested clones of Rhododendron microplants inoculated with strain Ipae 25 (table II). Substratum bf 3 used at $\mathrm{pH} 4.5$ gave best results for weaning of all Rhododendron plantlets, and significant mycorrhizal growth responses were observed for clones 124 and 206. For each of these clones, the coefficient of variation indicated that the mycorrhizal plant population was more homogenous than the non infected one. Stekmedium had good early effects but plant growth slowed down by 8 wk. In general, mycorrhization caused an increase in plant growth of clones on Stekmedium, whilst clones were generally less responsive on Floratorf and Hortipro. There was an effect of $\mathrm{pH}$ for substratum bf3, plant growth being generally lower at $\mathrm{pH}$ 6.0 than $\mathrm{pH} 4.5$. Infection was high $(50-80 \%)$ in

Table II. Effect of five nursery substrata on growth of 4 clones of mycorrhizal (+M) (Ipae 25) and nonmycorrhizal (NM) Rhododendron microplants.

\begin{tabular}{|c|c|c|c|c|c|}
\hline \multirow{2}{*}{$\begin{array}{l}\text { Rhodo- } \\
\text { dendron } \\
\text { clones }\end{array}$} & \multirow[t]{2}{*}{ Substrata } & \multicolumn{2}{|c|}{$\begin{array}{c}\text { Fresh weight } \\
\text { (mg) }\end{array}$} & \multicolumn{2}{|c|}{$\begin{array}{c}\% \text { coefficient } \\
\text { of variation }\end{array}$} \\
\hline & & $N M$ & $+M$ & $N M$ & $+M$ \\
\hline \multirow[t]{5}{*}{124} & bł3 $\mathrm{pH} 4.5$ & $28^{b^{\star}}$ & $73^{a}$ & 54.28 & 27.04 \\
\hline & Hortipro & $8^{b}$ & $9^{b}$ & 11.02 & 27.32 \\
\hline & Floratorf & $7^{b}$ & $10^{b}$ & 6.95 & 7.71 \\
\hline & Steklmedium & $8^{b}$ & $26^{b}$ & 5.67 & 29.61 \\
\hline & bf3 pH 6 & $g^{b}$ & $24^{b}$ & 3.30 & 21.17 \\
\hline \multirow[t]{5}{*}{206} & bf3 $\mathrm{pH} 4.5$ & $45^{b}$ & $123^{a}$ & 37.28 & 20.05 \\
\hline & Hortipro & $12^{c}$ & $17^{c}$ & 18.34 & 13.80 \\
\hline & Floratorf & $19 \mathrm{c}$ & $27 c$ & 28.16 & 21.88 \\
\hline & Stekmedium & $19^{c}$ & $91^{a}$ & 18.68 & 9.18 \\
\hline & bf3 pH 6 & $10^{c}$ & $22^{c}$ & 3.44 & 31.14 \\
\hline \multirow[t]{5}{*}{209} & bf3 $\mathrm{pH} 4.5$ & $106^{a}$ & $118^{a}$ & 29.47 & 17.45 \\
\hline & Hortipro & $36^{b}$ & $39 \mathrm{~b}$ & 28.92 & 9.53 \\
\hline & Floratorf & $21^{b}$ & $75^{\mathrm{ab}}$ & 17.88 & 12.86 \\
\hline & Stekmedim & $30^{b}$ & $64^{a b}$ & 23.11 & 13.78 \\
\hline & bf3 pH 6 & $42^{b}$ & $82^{a b}$ & 36.20 & 16.66 \\
\hline \multirow[t]{5}{*}{282} & bf3 $\mathrm{pH} 4.5$ & $33^{a b}$ & $48^{a}$ & 38.92 & 25.70 \\
\hline & Hortipro & $11^{b}$ & $15^{b}$ & 14.62 & 9.93 \\
\hline & Floratorf & $10^{b}$ & $21^{a b}$ & 22.03 & 23.56 \\
\hline & Stekmedium & $14^{b}$ & $34^{a b}$ & 9.23 & 11.49 \\
\hline & bf3 pH 6 & $20^{a b}$ & $31^{a b}$ & 34.25 & 18.15 \\
\hline
\end{tabular}

\footnotetext{
* Values for each clone followed by different letters are significantly different at $95 \%$ confidence levels.
}

bf3 and Floratorf, and low (10\%) in the other substrata. The former was therefore used for screening of endomycorrhizal fungal isolates.

\section{Screening of fungal isolates}

Some physiological specificity was observed between the different Rhododendron cultivars and the fungal isolates (table III). Significant positive effects on plant growth, as compared to noninoculated controls, were only observed for isolates Ipae 9 with clone 212 and Ipae 13 with clone 232, although significant differences between isolates regarding effect on plant growth were also observed for clones 119 and 200. Isolate Ipae 25 tended to improve growth and decrease heterogeneity (lower coefficients of variation) of the Rhododendron clones 119 and 200 , whilst positive effects of isolates Ipae 9 and 15 were observed with clones 117 and 209; in the latter, growth stimulation was also observed with isolate Ipae 42 . With clone 201 , the control became infected with mycorrhizal fungi, so there was no response. The mycorrhization by certain isolates was inclined to decrease heterogenity with smaller variations between plants (lower coefficient of variation) being related to positive growth effects for Rhododendron clones 117, 119, 136, 200 and 232. Improved homogeneity of the plantlet populations should constitute an important parameter for choice of the fungal strain. The mixture of isolates did not give better results than an isolate alone, indicating that it was sufficient to choose one specific fungal strain and that interactions between strains were not synergistic. Plant growth increase and root infection were not necessarily correlated. Some fungal isolates had negative effects on growth and homogeneity of certain Rhododendron clones (eg Ipae 25/clone 201), underlining the necessity to screen for beneficial combinations.

\section{CONCLUSIONS}

The results reported here clearly show that defined culture procedures should be adopted to ensure successful production of microplants of Rhododendron. It is essential to carefully choose substrata with an appropriate $\mathrm{pH}$ (4.5) and this should be disinfected before outplanting of microplants, in order to eliminate 
Table III. Growth of 5 clones of Rhododendron microplants outplanted into disinfected bf3 substratum and inoculated with different endomycorrhizal fungi.

\begin{tabular}{|c|c|c|c|}
\hline $\begin{array}{l}\text { Rhododendron } \\
\text { clones }\end{array}$ & $\begin{array}{l}\text { Fungal } \\
\text { strains }\end{array}$ & $\begin{array}{l}\text { Fresh mass } \\
(m g)\end{array}$ & $\begin{array}{l}\% \text { Coefficient } \\
\text { of variation }\end{array}$ \\
\hline \multirow[t]{7}{*}{110} & Ipa9 & $136^{a^{*}}$ & 11.70 \\
\hline & Ipa 13 & $197^{a}$ & 12.64 \\
\hline & Ipa 15 & $134^{a}$ & 6.64 \\
\hline & Ipa 25 & $122^{a}$ & 12.33 \\
\hline & Ipa 42 & $160^{a}$ & 12.65 \\
\hline & Mixture & $173^{a}$ & 9.80 \\
\hline & Control & $174^{a}$ & 13.53 \\
\hline \multirow[t]{7}{*}{117} & Ipa 9 & $178^{a}$ & 6.32 \\
\hline & Ipa 13 & $141^{a}$ & 20.23 \\
\hline & Ipa 15 & $175^{a}$ & 9.48 \\
\hline & lpa 25 & $116^{a}$ & 23.08 \\
\hline & Ipa 42 & $109^{a}$ & 16.76 \\
\hline & Mixture & $132^{a}$ & 11.06 \\
\hline & Control & $109^{a}$ & 13.60 \\
\hline \multirow[t]{7}{*}{119} & Ipa 9 & $67^{a b}$ & 23.40 \\
\hline & Ipa 13 & $48^{b}$ & 22.50 \\
\hline & Ipa 15 & $40^{b}$ & 28.60 \\
\hline & Ipa 25 & $115^{a}$ & 16.09 \\
\hline & Ipa 42 & $83^{a b}$ & 22.01 \\
\hline & Mixture & $48^{b}$ & 22.60 \\
\hline & Control & $65^{a b}$ & 16.38 \\
\hline \multirow[t]{7}{*}{136} & Ipa 9 & $326^{a}$ & 41.41 \\
\hline & Ipa 13 & $303^{a}$ & 13.43 \\
\hline & Ipa 15 & $345^{a}$ & 17.31 \\
\hline & Ipa 25 & $410^{a}$ & 16.19 \\
\hline & Ipa 42 & $345^{a}$ & 16.55 \\
\hline & Mixture & $257^{a}$ & 11.20 \\
\hline & Control & $283^{a}$ & 16.61 \\
\hline \multirow[t]{2}{*}{200} & Ipa 9 & $54^{a b}$ & 13.54 \\
\hline & Ipa 13 & $45^{a b}$ & 49.18 \\
\hline
\end{tabular}

harmful fungi. It would also be advantageous to inoculate microplants with an appropriate endomycorrhizal ericoid fungus adapted to both the substratum and plant clone, in order to ensure optimal growth and homogenous production of microplants.

\section{ACKNOWLEDGMENTS}

The authors thank the Pépinières Derly France for supplying the plant material and for financial support to MC Lemoine and are grateful to C Pimet for technical assistance.

\begin{tabular}{|c|c|c|c|}
\hline & Ipa 15 & $47 a b$ & 22.38 \\
\hline & Ipa 25 & $82^{a}$ & 16.47 \\
\hline & Ipa 42 & $41^{b}$ & 15.97 \\
\hline & Mixture & $46^{a b}$ & 16.90 \\
\hline & Control & $50^{a b}$ & 17.22 \\
\hline 201 & Ipa 9 & $97^{a}$ & 17.99 \\
\hline & Ipa 13 & $60^{a b}$ & 12.99 \\
\hline & Ipa 15 & $49^{b}$ & 19.37 \\
\hline & Ipa 25 & $106^{a}$ & 17.74 \\
\hline & Ipa 42 & $124^{a}$ & 22.1 \\
\hline & Mixture & $99^{a}$ & 10.62 \\
\hline & Control & $124^{a}$ & 22.2 \\
\hline 209 & Ipa 9 & $1181^{a}$ & 12.64 \\
\hline & Ipa 13 & $803^{a}$ & 15.74 \\
\hline & Ipa 15 & $1230^{a}$ & 10.0 \\
\hline & Ipa 25 & $886^{a}$ & 19.83 \\
\hline & Ipa 42 & $1177^{a}$ & 7.50 \\
\hline & Mixture & $1190^{a}$ & 15.9 \\
\hline & Control & $860^{a}$ & 15.50 \\
\hline 212 & Ipa 9 & $441^{a}$ & 19.07 \\
\hline & Ipa 13 & $340^{\mathrm{ab}}$ & 24.3 \\
\hline & Ipa 15 & $295^{a b c}$ & 14.78 \\
\hline & Ipa 25 & $294^{a b c}$ & 13.29 \\
\hline & Ipa 42 & $283^{a b c}$ & 7.03 \\
\hline & Mixture & $202^{b c}$ & 14.38 \\
\hline & Control & $134^{\mathrm{bc}}$ & 18.55 \\
\hline 232 & Ipa 9 & $210^{b c}$ & 14.34 \\
\hline & Ipa 13 & $450^{a}$ & 12.99 \\
\hline & Ipa 15 & $353^{a b}$ & 10.69 \\
\hline & Ipa 25 & $169^{\circ}$ & 13.01 \\
\hline & Ipa 42 & $217^{b c}$ & 16.15 \\
\hline & Mixture & $281^{b c}$ & 13.73 \\
\hline & Control & $305^{b c}$ & 19.70 \\
\hline
\end{tabular}

* Values for each clone followed by different letters are significantly different at $95 \%$ confidence levels.

\section{REFERENCES}

Beaujard F (1982) Problèmes posés par la mycorhization des bruyères en pépinières. $C R$ Séances $A c a d$ Agric 68 (2), 1178-1192

Douglas GC, Heslin MC, Reid C, 1989 Isolation of Oidiodendron maius from Rhododendron and ultrastructural characterization of synthesized mycorrhizas. Can J Bot 67, 2206-2212

Duddridge J, Read DJ (1982) An ultrastructural analysis of the development of mycorrhizas in Rhododendron poncticum. Can J Bot 60, 2345-2356

Gianinazzi-Pearson V, Gianinazzi S (1981) Role of endomycorrhizal fungi in phosphorus cycling in the ec- 
osystem. In: The Fungal Community. Its Organization and Role in the Ecosystem Mycology Series (Wicklow DT, Caroll GC, eds) 2 (33), 637-652

Moore-Parkhurst S, Englander L (1981) A method for the synthesis of a mycorrhizal association between Pezizella ericae and Rhododendron maximum seedlings growing in a defined medium. Mycologia 73, 994-997

Moore-Parkhurst S, Englander L (1982) Mycorrhizal status of Rhododendron spp in commercial nurseries in Rhode Island. Can $J$ Botany 60, 23422344
Perterson TA, Mueller WC, Englander L (1980) Anatomy and ultrastructure of a Rhododendron rootfungus association. Can J Botany 58 (23), 24212433

Read DJ, Bajwa R (1985) Some nutritional aspects of the biology of the ericaceous mycorrhizas. Proc $R$ Soc Edinburgh 85B, 317-332

Straub S (1988) Amélioration de la multiplication, de la conservation et de l'acclimatation du Rhododendron par utilisation des vitrométhodes et de la mycorhization. Mém Fin d'Etudes, Ecole Nat Sup Hortic Versailles, 144 pp 